\title{
Microbiological indicators of water quality in the Xochimilco canals, Mexico City
}

\author{
Luis A Ifredo Juárez-Figueroa, MD, (1) Jesús Silva-Sánchez, PhD, (1) Felipe Javier U ribe-Salas, MD, MPH, MSc, ${ }^{(1)}$ \\ Enrique C ifuentes-García, PhD.(1)
}

\begin{abstract}
Juárez-Figueroa LA, Silva-Sánchez J, Uribe-Salas FJ, Cifuentes-García E. Microbiological indicators of water quality in the Xochimilco canals, Mexico City. Salud Publica Mex 2003;45:389-395. The English version of this paper is available too at: http://www.insp.mx/salud/index.html
\end{abstract}

\begin{abstract}
Objective.To quantify microbiology indicators of fecal contamination in the effluents of two waste water treatment plants and in samples collected in several canals in X ochimilco. Material and Methods.A cross sectional study was performed. Ten sites, 5 from plant effluents and 5 from canals, were selected for sampling during November and December 2001. Fecal coliforms and enterococci were quantified by membrane filtration, male specific $\left(\mathrm{F}^{+}\right)$and somatic coliphages by double agar layer technique, and Cryptosporidium oocysts and Giardia cysts by concentration with Envirocheck filter followed by immunofluorescence microscopy quantification. The average of organisms counts from effluents and canal water were compared with $t$ Student test. Results. Treated water discharge in canals showed a low count of Fecal Coliforms (average 40.4/100 ml), enterococci (average 58.8/100 ml) and Cryptosporidium oocysts (average 13.2/100 I), while coliphages and Giardia cyst rendered higher counts (average 1467.5/100 ml and 1199.8/100 I, respectively) suggesting the water treatment methods could fail to remove these agents. A significant lower count of Giardia cysts (average 45/100 I) and no Cryptosporidium 00 cysts were found in irrigation canals, which suggests a natural clearance of these pathogens. Strains of Escherichia coli isolated in one of the canals contaminated with sewage had antimicrobial multi-resistance that was transferred by
\end{abstract}

\author{
Juárez-Figueroa LA, Silva-Sánchez J, \\ Uribe-Salas FJ, Cifuentes-García E. \\ Indicadores microbiológicos de la calidad del agua \\ de los canales de Xochimilco de la Ciudad de México. \\ Salud Publica Mex 2003;45:389-395. \\ El texto completo en inglés de este artículo también \\ está disponible en: http://www.insp.mx/salud/index.html
}

\section{Resumen}

Objetivo. Cuantificar diversos indicadores de contaminación fecal en los efluentes de dos plantas de tratamiento de aguas residuales y en muestras recogidas en varios canales de Xochimilco. Material y métodos Estudio transversal efectuado en X ochimilco, México. D urante noviembre y diciembre de 2001 se muestrearon 10 sitios, cinco efluentes y cinco canales, para la cuantificación de coliformes fecales y enterococos (filtración en membrana de nitrocelulosa), colifagos somáticos (técnica de doble capa de agar), ooquistes de Cryptosporidium sp.y quistes de Giardia sp. (concentración en filtros Envirocheck y microscopía de inmunofluo rescencia). Se efectuó comparación de los promedios de las cuentas de organismos hallados, en efluentes y canales, mediante t de Student. Resultados El agua tratada que descarga en los canales mostró cantidades bajas de coliformes fecales (media de 40.4/100 ml), enterococos (media de 58.8/ $100 \mathrm{ml}$ ) y quistes de Cryptosporidium (media de 13.2/100 I), mientras que los colifagos y quistes de Giardia estuvieron presentes en gran cantidad (media de 1467.5/100 ml y $1199.8 / 100$ l, respectivamente), sugiriendo que el tratamiento del agua puede ser ineficaz para remover estos agentes. En los canales de irrigación de vegetales se encontró una cantidad significativamente menor de quistes de Giardia (media de 45/100 I) y no se encontraron ooquistes de Cryptosporidium, lo que sugiere la remoción natural de estos agentes.

This study was financed by the Instituto Nacional de Salud Pública, México and by the University of South Florida, USA.

This work was undertaken during a sabbatical at the University of South Florida, USA.

(1) Instituto Nacional de Salud Pública. Cuernavaca Morelos, México.

Received on: January 20, $2003 \cdot$ Accepted on: August 1, 2003

Address reprint request to: Luis A Ifredo Juárez-Figueroa. Instituto N acional de Salud Pública. Avenida Universidad 655 colonia Santa María A huacatitlán, 62508 Cuernavaca, Morelos, México.

Email: luisjuarez@.insp.mx 
conjugation suggesting that resistance is encoded in a plasmid potentially transferable to other pathogenic bacteria. Conclusions. Cost effective and culturally acceptable waste treatment methods will require careful planning and consultation if they are to be adopted and mantained by local populations. The English version of this paper is available too at: http://www.insp.mx/salud/index.html

Key words: water quality; fecal contamination; sanitation; Mexico
Algunos aislamientos de $\mathrm{E}$ coli obtenidos de un canal contaminado con descargas cloacales mostraron una multirresistencia a antibióticos que fue transferida por conjugación a o tras bacterias mediante plásmidos. Esto sugiere la posible diseminación de la resistencia a bacterias del medio (posibles patógenas). Existen numerosos asentamientos humanos cercanos a las chinampas que descargan desechos directamente a los canales. Conclusiones La implantación de métodos de tratamiento de excretas que resulten costeables y culturalmente aceptables debe realizarse mediante una cuidadosa planeación y consulta, si estos métodos han de ser adoptados y sostenidos por la población local. El texto completo en inglés de este artículo también está disponible en: http://www.insp.mx/salud/index.html

Palabras clave: calidad del agua; contaminación fecal; saneamiento; México
M exico City's wastewater system includes multiple open sewer canals, sewer reservoirs, lagoons, pumping stations, and deep drainage systems. Approximately $75 \%$ of the population has access to this wastewater system, while the rest dispose of their sewage through septic tanks and absorption wells.

Twenty seven wastewater treatment plants treat approximately $7 \%$ of the wastewater generated in Mexico City. However, these plants generally operate at less than 50 percent efficiency, treating $4.3 \mathrm{~m}^{3} / \mathrm{sec}$.

Untreated wastewater irrigation of vegetables which may be eaten raw is not allowed, whereas a range of crops (i.e. cereals and fodder) can be irrigated with an effluent containing no more than 1000 FC per $100 \mathrm{ml}^{1,2}$ Some farm settings in Mexico receive wastewater meeting quality recommendations. One of the most important sites is Xochimilco, where the effluent $\left(5 \mathrm{~m}^{3} / \mathrm{sec}\right)$ from a secondary treatment plant (activated sludge process and chlorination) flows through the canals and is used for irrigation of flowers, fodder, maize and vegetables, and aquifer recharge.

Xochimilco is located along the southeast edge of Mexico City, and is the remnant of a pre-Hispanic farming system initiated during the 13th century on the edge of a lake basin. Clusters of agricultural plots ("chinampas"), enclosed by interwoven poles of reeds and framed by canals, result in a highly efficient irrigation scheme. These plots were originally built by accumulating layers of mud, dredged from the bottom of the lake, and then deposited upon marshes or shallow lake areas.

The case of Xochimilco is an example of the growing conflict regarding availability of groundwater between cities and the countryside. Increasing volumes of groundwater are extracted for Mexico City's expansion, depleting resources and forcing Xochimilco to turn to using partially treated wastewater. In addition, open canals are subject to non-point source illegal discharge from farms and new homesteads. ${ }^{3}$ The water source for agricultural production is crucial in these areas, since vegetables grown in Xochimilco are commercialized for consumption throughout Mexico City.

The effect of point source contamination from irregular settlements and leakage from the overwhelmed public sewage system could cancel out the expected effect of treatment plants installed for maintenance of the irrigation needs for crops grown on "chinampas".

Additionally, this contamination could facilitate the transmission of enteropathogenic agents through contaminated crops and through direct contact with agricultural workers.

During a previous study, we encountered a high prevalence of Giardia intestinalis infection among asymptomatic children from urban settlements in the Xochimilco area. This infection is endemic in this area.*

Another agricultural area receiving most of the wastewater generated in Mexico City, the Mezquital Valley, has a high prevalence of Giardia infections among children. ${ }^{4}$

Despite the increasing importance of this problem, there is a surprising lack of data addressing the health risks associated with the microbiological quality of irrigation water in Xochimilco.

The present study provides baseline data on the microbiology quality of water in Xochimico canals using diverse indicators for fecal contamination and pres-

\footnotetext{
* Cifuentes E, Suárez L, Espinoza M, Juárez-Figueroa L, MartínezPalomo A. The risk of Giardia intestinalis. Infection in children from on artificially recharged ground water site in Mexico City. Unpublished data.
}

salud pública de méxico / vol.45, no.5, septiembre-octubre de 2003 
ence of protozoan pathogens. Water samples were collected from the effluents of two treatment plants before discharge to canals in Xochimilco, as well as from diverse sites along the canals.

\section{Material and Methods}

\section{Sample sites}

A topographic chart of the Xochimilco area (INEGI E14B39), along with reports from the local population, were used to select ten sites for sample collection. These sites included: a) all points where treated water was discharged into the canals, b) four canals that irrigate the largest crop areas, and c) a canal having point source contamination. Samples were collected during the dry season between November and December 2001.

A water sample was collected from the original effluent at each of the five points where treated water is discharged into the canals. Three of the sampled sites receive the effluent from "Cerro de la Estrella" plant: Fernando Celada pier (EFC1; W 99.108 , N 19.264), San Diego pier (ESD2; W 99.099, $\left.\mathrm{N} 19.264^{\circ}\right)$, and Xochimilco Ecologic Park (PE5; W 99.094 , N 19.296). Two of the sampled sites receive effluent from the San Luis plant: Zacapa pier (EZ3; W 99.092 $\left.{ }^{\circ}, \mathrm{N} 19.250^{\circ}\right)$ and Acuexcomatl canal (Acu4; W 99.032 , N 19.258 $)$. Samples of water currently used to irrigate vegetables were collected at 20-30 cm depth from four canal sites: Huerolodo canal (CH7; W 99.101 , N 19.275), Canal Nacional (CN8; W 99.094 $\left.{ }^{\circ}, \mathrm{N} 19.276^{\circ}\right)$, Apampilco canal $\left(\mathrm{CA} 10 ; \mathrm{W} 99.095^{\circ}, \mathrm{N} 19.273^{\circ}\right)$, and Cuemanco canal (CC12; W 99.101 ${ }^{\circ}$ N $\left.19.285^{\circ}\right)$. Finally, a sample was collected from the canal next to the San Diego pier (ESD6; W 99.099 ${ }^{\circ}, \mathrm{N} 19.263^{\circ}$ ), where a leaking sewage system runs into the canal (Figure 1).

One-liter samples for bacteria and bacteriophage assays were collected in Nalgene ${ }^{\mathrm{TM}}$ polyvinyl bottles,



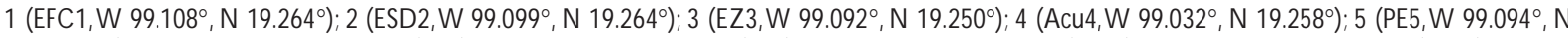

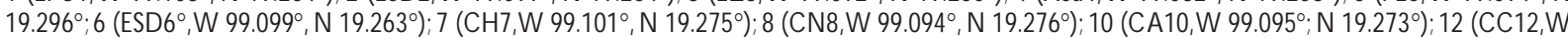
$\left.99.101^{\circ}, \mathrm{N} 10.285^{\circ}\right)$

\section{Figure 1.T reated water effluents $(1,2,3,4$, ANd 5) AND Canals $(6,7,8,10$, AND 12$)$ SAMPLing Sites in Xochimilco, MeXICO, 2001}


stored at $4{ }^{\circ} \mathrm{C}$ and transported to the Instituto Nacional de Salud Pública (National Institute of Public Health) in Cuernavaca (40 miles). Assays for detection of fecal coliform, enterococci and bacteriophage were conducted within 24 hours of sample collection. Bacteria were quantified using the membrane filter technique. $^{5}$

Sample volumes (dependent on the expected bacterial density) were filtered through $0.45 \mu \mathrm{m} \_47 \mathrm{~mm}$. diameter filters. All samples were run in duplicate. Positive and negative controls were included for each batch.

For fecal coliform (FC) identification, filters were placed on $\mathrm{mFC}$ (Fecal Coliform agar medium) and incubated overnight at $44.5^{\circ} \mathrm{C}$ in a waterbath. Blue colonies were counted as FC.

A representative number of colonies was tested for antibiotic sensitivity on Luria plates supplemented with the following antibiotics at fixed concentrations: ampicillin (ap, $100 \mu \mathrm{g} / \mathrm{ml}$ ); cefotaxime (Ctx, 1 $\mu \mathrm{g} / \mathrm{ml})$; ceftazidime $(\mathrm{CAZ}, 1 \mu \mathrm{g} / \mathrm{ml})$; tetracycline (tc, $12.5 \mu \mathrm{g} / \mathrm{ml})$; kanamycin $(\mathrm{km}, 25 \mu \mathrm{g} / \mathrm{ml})$; gentamycin (gm, $16 \mu \mathrm{g} / \mathrm{ml})$, and chloramphenicol (cm, $10 \mu \mathrm{g} / \mathrm{ml})$.

Those colonies having antibiotic multiresistance were further identified with the API E20 system (BioMerieux, Merck, France). $\beta$-Lactamase production was detected with nitrocephine solution $(500 \mu \mathrm{g} / \mathrm{ml})$, (Oxoid, UK). Resistance transfer experiments were performed as described (Miller, 1972) using E coli J53-2 as the receptor strain. Transconjugants were selected on Luria agar supplemented with rifampin (100 $\mu \mathrm{g} / \mathrm{ml})$ in combination with ampicillin $(100 \mu \mathrm{g} / \mathrm{ml})$ or tetracycline $(15 \mu \mathrm{g} / \mathrm{ml})$.

For enterococci identification, filters were placed on mEI (Enterococci Indel agar medium) and incubated 24 hours at $41^{\circ} \mathrm{C}$. Blue colonies were counted as enterococci. A representative number of colonies from each plate were typified using Microscan ${ }^{\mathrm{TM}}$ (Dade Behring, Germany).

Male-specific $\left(\mathrm{F}^{+}\right)$and somatic coliphage counts were conducted using a double agar layer method, ${ }^{6}$ adapted according to method 1601 of the US Environmental Protection Agency.

Cryptosporidium and Giardia analysis: Samples were processed and assayed for enteric protozoa by filtration and immunofluorescence microscopy techniques according to method 1623 of the US Environmental Protection Agency.

Samples were collected by filtration through Envirocheck HV filters (Gelman Inc.) and sent for analysis to the Laboratory of Water Pollution, College of Marine Sciences, University of South Florida, USA.
Bacteria, coliphage, and protozoan counts from effluent and irrigation canals were compared using Student's $t$ test.

\section{Results}

Samples collected at Cerro de la Estrella effluent discharge sites had an average of 3.2/100 ml FC. The effluent at EFC1 had 78/100 $\mathrm{ml}$ enterococci (typified as E gallinarum), while at the other two sites corresponding to Cerro de la Estrella, ESD2 and PE5, no enterococci were found. Coliphage counts were 940/100 ml on average (Table I).

Cryptosporidium oocyst and Giardia cyst concentrations at EFC1 were 30/100 1 oocysts and 1390/100 1 cysts, respectively. At ESD2, they were 20/100 l oocysts, and 1910/100 1 cysts, respectively. At PE5, no Cryptosporidium oocysts, and only one Giardia cyst were observed from the sample volume analyzed (20 l), which corresponds to $6.66 / 1001$ cysts (Table I).

FC in samples collected from the San Luis plant effluent discharge sites were $2.5 / 100 \mathrm{ml}$ at EZ3 and 190/100 $\mathrm{ml}$ at Acu4. Enterococci counts were 1/100 ml at EZ3 (not typified) and 215/100 $\mathrm{ml}$ (typified as $E$ durans) at Acu4. Coliphage counts were 3050/100 ml at Acu4. The sample for coliphage counts at EZ3 was lost.

\section{Table I}

\section{MicRobiologicAL INDICATORS FROM PLANT EFFLUENTS ANd CANal Water In Xochimilco, MeXico, 2001}

\begin{tabular}{|c|c|c|c|c|c|}
\hline Sample code & $\begin{array}{l}\text { Fecal coliform } \\
\text { in } 100 \mathrm{ml}\end{array}$ & $\begin{array}{l}\text { Enterococci } \\
\text { in } 100 \mathrm{ml}\end{array}$ & $\begin{array}{l}\text { Coliphages } \\
\text { in } 100 \mathrm{ml}\end{array}$ & $\begin{array}{l}\text { Cryptosporidiu } \\
\text { in } 1001\end{array}$ & $\begin{array}{l}\text { am Giardia } \\
\text { in } 100 \text { I }\end{array}$ \\
\hline E.F.C.1* & 7.5. & 78 & 1350 & 30 & 1390 \\
\hline E.S.D.2* & 1 & 0 & 450 & 20 & 1910 \\
\hline P.E.5* & 1 & 0 & 1020 & $(0)<6.66$ & 6.66 \\
\hline E.Z.Z. & 2.5 & 11 & N ot done & 10 & 1755 \\
\hline$\overline{\mathrm{Acu}} .4^{\ddagger}$ & 190 & 215 & 3050 & 6.25 & 937.5 \\
\hline $\mathrm{C} . \mathrm{H} .7^{\S}$ & 110 & 265 & 200 & $(0)<40$ & (0) $<40$ \\
\hline C.N. $8^{\S}$ & 50 & 140 & 1100 & $(0)<20$ & 80 \\
\hline C.A.10ई & 130 & 285 & 150 & $(0)<25$ & 100 \\
\hline C.C.12 & 100 & 250 & 20 & $(0)<22$ & $(0)<22$ \\
\hline E.S.D.6\# & 80500 & 52000 & 97500 & 120 & 5530 \\
\hline
\end{tabular}

* Samples from effluent of Cerro de la Estrella plant at: Fernando Celada pier (E.F.C.1), San Diego pier (E.S.D.2) and Ecologic Park (P.E.5)

₹ Samples from effluent of San Luis Plant at: Zacapa pier (E.Z.3) and Acuexcomatl canal (Acu.4)

§ Samples from irrigation canals at: Huerolodo canal (C.H.7), Nacional canal (C.N .8),A pampilco canal (C.A. 10) and C uemanco canal (C.C.12)

\# Sample from the canal at San Diego pier 
Cryptosporidium oocysts at EZ3 were 10/100 l, whereas no oocysts were found at Acu4. Giardia cysts were 1755/100 1 at EZ3 and 937.50 at Acu4 (Table I).

The average FC count in four canals from which water is used for vegetable irrigation was $97.5 / 100 \mathrm{ml}$, while enterococci average counts were 235/100 ml (typified as E. faecium at $\mathrm{CN} 8$ and E. faecalis in the other sites) and coliphages were $367.5 / 100 \mathrm{ml}$.

No Cryptosporidium oocysts were observed in irrigation canals. Giardia cyst counts were $80 / 1001$ at CN8, 100 / 1001 at CA10; none were found at CH7 and CC12 (Table I).

In the canal next to San Diego pier (ESD6) FC counts were $80500 / 100 \mathrm{ml}$. Enterococci count was 52 000/100 ml (typified as E faecium), and coliphages were 97 500/100 ml. Cryptosporidium oocyst and Giardia cyst counts were 120/100 l and 5530/100 1, respectively (Table I).

A total of 235 coliform colonies were tested to identify susceptibility to antibiotics. All colonies were susceptible to third generation cephalosporines (Ctx and CAZ). Two major resistance frequencies were observed: to tetracycline in 108 of 235 colonies (46\%), and to ampicillin in 82 of 235 colonies (34.5\%). Only $23.4 \%$ of the colonies were resistant to one antibiotic, $9.8 \%$ to two antibiotics, $6.8 \%$ to three antibiotics, and $8.5 \%$ to four or five antibiotics.

The highest resistance frequencies were obtained from sample ESD6 at San Diego pier, in which 95\% of the colonies were resistant to tetracycline, $87 \%$ to ampicillin, and 33\% for three resistance markers. The second highest resistance frequency was from Acu4 (San Luis plant effluent) with $69 \%$ for tetracycline, and $56 \%$ for ampicillin.

Fourteen multiresistant bacterial strains all corresponded to Escherichia coli. Ten of these strains had a low susceptibility to tetracycline and ampicillin, and were tested for their ability to transfer tetracycline and ampicilin resistance by conjugation to other bacteria. Results showed that five matings (two from ESD6, two from Acu4 and one from CC12 samples) were successful in transferring the resistance to tc, ap, $\mathrm{km}$, $\mathrm{gm}$, and $\mathrm{cm}$.

\section{Discussion}

Xochimilco's "chinampas" represent the last remnant of a highly productive agriculture strategy which established the economy of the Valley of Mexico during pre-Hispanic times. Chinampas, along with their inhabitants, stand today as a self-sufficient competitive economy by using the same type of land reclamation and agricultural methods after more than 700 years of known history, and is considered a heritage to be preserved. 7,8

All of the samples analyzed in this study were collected during the dry season. Despite the fact that "chinampas" are not normally irrigated with canal water during the rainy season, a broader sampling scheme including both dry and rainy seasons will be required in the future to determine the variability of conditions affecting contamination of Xochimilco's canal water.

"Chinampa" soils have traditionally been managed intensively. Soil fertility is continuously renewed with organic material, such as canal mud, aquatic plants, crop and weed residues, and animal manure. In addition, family and social organization have also been important factors in the survival of the "chinampas", and those projects aimed at protecting and encouraging the use and production by "chinampas" must consider its sociocultural attributes. ${ }^{9}$

Protection against the discharge of untreated urban wastewater into the canals is the responsibility of Mexico City's government. If health risks are to be contained in Xochimilco, periodic inspection of the sewage network should be conducted and failures of the system remedied promptly. Unfortunately, at the time of this study there was a sewage leak at San Diego pier unattended by authorities. Since one of the primary functions of the San Diego pier, is the offloading of flowers from family maintained "chinampas", and since school age children are the primary work force for this activity, the continued presence of contaminated water represents an specific exposure for this population group.

A treated water effluent approximately $20 \mathrm{~m}$ upstream of this site (ESD2 on Table I) had very low FC counts and no enterococci, while high counts were measured for coliphages and Giardia cysts at the same site. Downstream from ESD2, the water in San Diego canal is contaminated by a sewage leak, with high counts for all enteric pathogens, except Cryptosporidium (ESD6 on Table I). E coli isolated from the canal was multiresistant to tc, ap, gm, $\mathrm{km}$ and $\mathrm{cm}$ antibiotics. Antimicrobial resistance transferred by conjugation, suggests that resistance genes are encoded in a plasmid that could be transferred to other promiscuous pathogenic bacteria. ${ }^{10,11}$ Evidence for plasmid-mediated antibiotic multiresistant environmental strains has been reported from Mexico City, indicating that such mechanisms may have a greater epidemiological impact than previously expected, ${ }^{12}$ as dissemination of resistance antibiotic genes could be transferred to other bacteria in animals or human gut and will be selected by the use of antibiotics. Further studies using 
antibiotic resistance patterns ${ }^{13,14}$ will be useful in assessing sources of fecal contamination in Xochimilco waters.

Mexico has adopted a water quality standard of a daily mean of $\leq 2000 \mathrm{FC} / 100 \mathrm{ml}$ and a monthly mean of $\leq 1000 \mathrm{FC} / 100 \mathrm{ml}$ for wastewater used in unrestricted irrigation (for uses that include crops likely to be eaten uncooked). ${ }^{15}$ However there are no official standards for protozoan and enterovirus counts for unrestricted irrigation water. The present study encountered FC counts that meet the required quality from both Cerro de la Estrella plant and San Luis plant effluents. Nevertheless, variable coliphage counts were encountered and Giardia cyst counts were consistently high in all effluents except PE5, suggesting that water treatment methods failed to remove these organisms (Table I).

No Cryptosporidium oocysts, although significantly lower counts for Giardia, were found in irrigation canal water, suggesting their natural clearance due to water flow (Table II). There was no difference in FC and coliphage counts between irrigation canals and treatment plant effluents, although enterococci counts in irrigation canal water were significantly higher, suggesting waste contamination in canals (Table II).

Xochimilco's Ecological Park acts as a regulatory lagoon and receives better quality treated water than other sites (PE5, Table I). However, coliphage counts were as high in PE5 as they were in most samples tested, suggesting that these and enteric viruses are the most resistant to environmental conditions and water treatment methods. ${ }^{16,17}$

The sociocultural context of the chinampas has provided agricultural continuity for the resident population, at the cost of health risks. Many households near chinampas dispose of untreated waste directly

Table II

STATISTICAL DIFFERENCES FOR WATER INDICATORS (AVERAGE COUNT) FROM PLANT EFFLUENTS ANd IRRIgation Canals In Xochimilco, MeXico, 2001

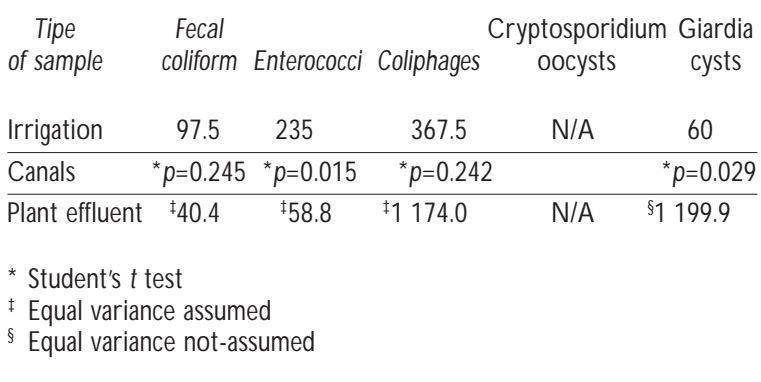

into the canals, while untreated cattle manure used as fertilizer implies exposure to pathogens such as Giardia. Cost-effective and culturally acceptable waste treatment methods will require careful planning and consultation if such methods are to be adopted and sustained by local populations.

\section{Acknowledgements}

To Dr. Joan Rose and Dr. Walter Quinteros-Betancourt of the College of Marine Sciences, University of South Florida, USA. To B. Biol. Rosalba Serralde for her valuable guidance on fieldwork. To M.Sc. Gabriela Echániz, INSP, who performed enterococci typification. To Technician Víctor Guerrero-Lemus, INSP, who collaborated on laboratory work. To M.Sc. Humberto Vázquez and MC. René Santos, INSP, who realized the mapping work. To Dr. Carlos Conde-González and Dra. Janine Ramsey, INSP, who revised the manuscript.

\section{References}

1. Ezcurra E. Mazari-H iriart M. A re megacities viable? A cautionary tale from Mexico City. Environment 1996;38:6-35.

2.W orld Health $\mathrm{O}$ rgan. Health guidelines for the safe use of wastewater in agriculture and aquaculture.W orld Health 0 rgan Tech Rep 1989. Ser 778.

3.Valdespino J, Parrilla M, Sepúlveda J, Díaz J, C amacho M, Luna J. Calidad del agua en la ciudad de México en relación a los sismos de septiembre de 1985. Salud Publica Mex 1987;29:412-420.

4. Cifuentes E, Gómez M, Blumenthal U,Téllez-Rojo M, Romieu I, Ruiz-Palacios $G$ et al. Risk factors for $G$ iardia intestinalis infection in agricultural village practicing wastewater irrigation in Mexico. Am J Trop Med Hyg 2000;62:388-392.

5. G reenberg AE, Eaton AD. Standard methods for the examination of water and wastewater 20th. edition.A merican Public Health Association, A merican W ater W orks Association, W ater Environment Federation. 1998.

6. Adams M. Bacterio phages. N ueva York (N Y). Interscience Pub, 1959. 7. Rojas T. Chinampas: un legado. Mexico Indigena 1990; 6: $42-45$. 8. Coe MD.The Chinampas of Mexico. Scientific American 1964;211: 90-98.

9. Jiménez-0 sornio J, D el Amo S.An intensive Mexican traditional agroecosystem:The "chinampa". Proceedings of the Sixth International Scientific Conference of the International Federation of 0 rganic A griculture Movements; 1986 A ugust 18-21; Santa C ruz, C alifornia, USA. 10. Hughes VM, D atta N . C onjugative plasmids in bacteria of the "preantibiotic" era. Nature 1983;302:725-726.

11. N euwirth C, Siebor E, López J, Pechinot A, Kazmierczak G. 0 utbreak of TEM-24 producing Enterobacter aerogenes in an intensive care unit and dissemination of the extended-spectrum B-lactamase to other members of the family Enterobacteriaceae. J C lin Microbiol 1996;34: 76-79.

12. Rosas I, Salinas E, Yela A, C alva E, Eslava C, C ravioto A. Escherichia coli in settled-dust and air samples collected in residential environments in Mexico City.Appl Environ Microbiol 1997;63:4093-4095. 
13. Harwood VJ,W hitlock J,W ithington V. C lassification of antibiotic resistance patterns of indicator bacteria by discriminant analysis: $U$ se in predicting the source of fecal contamination in subtropical waters. Appl Environ Microbiol 2000; 66:3698-3704.

14. W iggins $B, A$ ndrews R, Conway R, Corr C, D obratz E, D ougherty D et al. Use of antibiotic resistance analysis to identify nonpoint sources of fecal pollution. Appl Environ Microbiol 1999;65:3483-3486.

15. Blumenthal UJ, Mara DD, Peasey A, Ruiz-Palacios G, Stott R.

Guidelines for the microbiological quality of treated wastewater used in agriculture: Recommendations for revising W HO guidelines. Bull W orld Health 0 rgan 2000;78:1104-1116.

16. Leclerc H, Edberg S, Pierzo V, D elattre JM. Bacteriophage as indicators of enteric viruses and public health risk in groundwater. J Appl Microbiol 2000;88:5-21.

17. International Association on W ater Pollution, Research and Control. Study group on Health Related W ater Microbiology.W ater Res 1991;25:529-545. 